\title{
Observations on the Osazone Method of locating Sugars in Plant Tissues.
}

BY

SYDNEY MANGHAM, M.A.,

Lecturer in Botany, Armstrong College, Newcastle-on-Tyne, in the University of Durham.

\section{With Plate XVII.}

$\mathrm{T}$ the course of a research upon the paths of translocation of sugars in 1 plants it has often been necessary to determine the distribution of sugars in the tissues after the plants have been subjected to known external conditions.

The method which has been employed for this purpose is that introduced by Senft, ${ }^{1}$ and consists essentially in the production of osazones by means of a glycerine solution of phenylhydrazine acetate, a reagent having good penetrative powers.

Descriptions of the method and of some results obtained by it have already been published, ${ }^{2}$ but more recent investigations have thrown additional light on the value of the method and on the limits of its application. For this reason it is considered desirable to give in the present paper a more detailed account of the conclusions arrived at with regard to the use of Senft's reagent and to the interpretation of results yielded by it. In itself the paper forms a necessary prelude to the publication of results obtained in the above-mentioned research.

\section{GENERAL METHOD.}

The reagents employed are phenylhydrazine hydrochloride and sodium acetate dissolved separately in about ten times their weight of pure glycerine. ${ }^{3}$ Sodium acetate dissolves fairly readily in warm glycerine. The phenylhydrazine hydrochloride should be rubbed up with glycerine in a mortar, warmed and well shaken in a bottle kept stoppered to prevent

${ }^{3}$ Commercial glycerine is often adulterated with sugars. 
undue access of air. When solution is fairly complete this reagent should be warmed and filtered at least once.

Examined under a microscope, the liquid should be nearly free from brown particles or drops of phenylhydrazine hydrochloride. ${ }^{1}$ It should be kept in a darkened bottle preferably having a glass rod attached to the stopper for the withdrawal of drops.

For use, small quantities of the reagents are mixed on a slide, and the plant material is placed in the mixture, covered with a glass slip, and then heated in a water-jacketed oven for any desired time.

The preparation is then ready for examination, and provided that the material is not directly exposed to air by an insufficiency of the reagent, or other cause, nothing more need be done to the slide for some weeks.

It is very important to keep the tissues properly covered with the reagent, as otherwise brown oxidation products form.

Subsequently the sections may be removed, rinsed in cold water or dilute glycerine, and remounted in pure glycerine, the preparation then being sealed with a mixture of gum mastic and paraffin wax applied with a hot wire. ${ }^{2}$

If air bubbles are present in the tissues they can often be removed by an air-pump when the sections are in water or dilute glycerine.

Except when thick the sections generally become moderately clear in pure glycerine. If, however, it is desired to clear them further, weak $\mathrm{KOH}$ ( 2 per cent.) may be employed, after which the material should be well rinsed in water, or water to which a drop or two of acetic acid has been added.

Staining with aqueous stains can to a certain extent be carried out after the above treatment, but this is liable to decrease the transparency of the sections considerably. It is preferable to work with unstained material once familiarity has been gained with the structure of the tissues under investigation.

Strong glycerine produces some plasmolysis, but in practice this does not constitute a serious difficulty.

\section{DIFFUSION.}

To a certain extent diffusion of cell contents follows the application of the hot reagent, but the amount of this diffusion is less than that which occurs with aqueous reagents such as Fehling's solution.

In a section several cells thick the contents of the more deeply seated

${ }^{1}$ Such syrupy drops, if present in quantity, resemble the osazone syrup given by maltose (see below). Syrup found inside intact cells after treatment with the reagent could, however, hardly consist of small particles of phenylhydrazine hydrochloride, as these would have been filtered out by the cell membranes.

${ }^{2}$ Cf. Thomas ('11). 
cells naturally are less liable to diffusion than are the contents of more superficial cells.

Similarly, tissues in which intercellular spaces are rare or absent, e.g. phloem, are less affected by diffusion than are those in which such spaces are large or numerous, e. g. cortex, \&c.

Actual observations of numerous preparations give the impression that, after heating for an hour at $98^{\circ}-100^{\circ} \mathrm{C}$., diffusion from cells not injured by the razor is comparatively small, and that the crystals of osazones formed at the surface of the sections and in the medium away from the sections themselves are produced mainly from sugars which have escaped from the cut cells and have diffused into or have become mechanically mixed with the reagent during mounting and subsequent heating.

In support of this contention it may be stated that in numerous instances longitudinal sections of leaf-veins, examined for sugar distribution after the leaves had been darkened for suitable periods, have been found to show a distinct and fairly continuous gradient in the concentration of osazones, which concentration increases towards the proximal end of the vein irrespective of accidental variations in the thickness of the long, handcut sections.

Often, too, preparations have been examined in which fine sieve-tubes, arranged in a single layer, have alone formed a thin portion of the section, yet these have been found to be well filled with osazones.

As far then as intact cells are concerned the distribution of the osazones may be held to approximate closely to that of the reacting sugars present at the time of cutting the section.

In other words, positive results may be used fairly safely to locate certain sugars in the tissues, while negative results as a rule should not be attributed to diffusion of sugar present in the cells at the time of mounting.

It is well to note, however, that even when sugars are known to be present negative results may sometimes be given. ${ }^{1}$

\section{EFFECTS OF GLYCERINE.}

The use of glycerine in the reagent has several advantages. It penetrates rapidly, clears up the section, does not evaporate, is a good mounting medium, and owing to its viscosity diffusion of sugars, \&c., is less rapid in it than in water.

On the other hand, it has some effect upon the reaction with sugars, a point which does not appear to have received adequate attention at the hands of other botanical workers or critics who have dealt with it.

Various experiments have been carried out with a view to ascertaining

${ }^{1}$ See below, p. 373 . 
the effect of glycerine on the production of osazones from the four principal plant sugars, dextrose, levulose, maltose, and cane sugar.

As is well known, aqueous solutions of dextrose and levulose give with phenylhydrazine acetate long, fine, yellow, acicular crystals after a few minutes' heating at $100^{\circ} \mathrm{C}$. As a rule levulose deposits crystals before dextrose, the latter coming down on cooling. Microscopically the two osazones are usually indistinguishable. They are both fairly insoluble in cold water, but readily dissolve in alcohol.

Maltose, after being heated for an hour or more, produces a yellow syrup which crystallizes after standing for a longer or shorter period. Frequently these crystals look much like those given by dextrose and levulose, but more often they have a broader and flatter form, much like that of a sword blade, and they may be paler in colour.

Cane sugar, if pure, gives osazones only after becoming hydrolysed by prolonged heating. ${ }^{1}$ The resulting crystals are like those of dextrose and levulose.

A glycerine solution of the reagents is, however, used in Senft's method, and it has been found that the glycerine tends to hinder or prevent crystal formation to an extent which varies with the different sugars. This follows from the experiments now to be described.

Experiment $I$. Thirteen pairs of test-tubes were set up. Of these, ten pairs contained small and approximately equal amounts of one or other of the four sugars powdered and moistened. To each was added about 0.75 c.c. of the mixed reagent. The tubes were then completed by adding 2 c.c. of water to one set $(a)$, and 2 c.c. of glycerine to the other set (b). The other three pairs of tubes contained the reagent together with $(a)$ water, and $(b)$ glycerine, to serve as controls.

Tubes $\mathrm{I}-5$, i. e. a control pair + one pair of each kind of sugar, were then heated for 35 minutes at $98^{\circ} \mathrm{C}$.

Tubes $6-10$, i. e. a similar set, were heated for 60 minutes.

Tubes II-I3, i. e. a control pair + a pair containing cane sugar + a pair containing maltose, were heated for 75 minutes, after which the gas was turned off and the tubes were allowed to cool slowly in the bath.

The tubes were then examined periodically and gave results indicated in the table below.

1 Neutral aqueous solutions of cane sugar are slowly inverted on boiling. Watts, iv, p. $55^{\circ}$. 


\begin{tabular}{|c|c|c|c|c|}
\hline \multicolumn{2}{|c|}{ Heated 35 mins. } & \multirow{3}{*}{$\begin{array}{l}\text { On cooling. } \\
\text { No change. } \\
\text { Quite clear. }\end{array}$} & \multirow{3}{*}{$\begin{array}{l}\qquad \text { After } 4 \text { days. } \\
\text { Little change. } \\
\text { Quite clear. }\end{array}$} & \multirow{2}{*}{$\frac{\text { After } 5 \text { weeks. }}{\begin{array}{c}\text { Brown film at top; liquid } \\
\text { slightly turbid. }\end{array}}$} \\
\hline Cane sugar. & $(a)$ & & & \\
\hline$" \quad$, & (b) & & & $\begin{array}{l}\text { Top layers (I-2 mm.) slightly } \\
\text { turbid. No crystals. }\end{array}$ \\
\hline Maltose. & (a) & No change. & Little change. & $\begin{array}{l}\text { Brown film at top; liquid } \\
\text { slightly turbid. }\end{array}$ \\
\hline$"$ & (b) & Quite clear. & Quite clear. & $\begin{array}{l}\text { Liquid turbid at top only. } \\
\text { No crystals. }\end{array}$ \\
\hline Dextrose. & (a) & Very little osazone. & Very little osazone. & $\begin{array}{l}\text { Liquid slightly turbid. Only } \\
\text { very little osazone. }\end{array}$ \\
\hline$"$ & (b) & Quite clear. & Quite clear. & $\begin{array}{l}\text { Quite clear, except top layers } \\
\text { (I-2 mm.). No osazone } \\
\text { crystals visible. }\end{array}$ \\
\hline Levulose. & (a) & Abundant osazone. & Abundant osazone. & $\begin{array}{l}\text { Liquid slightly turbid. Osa- } \\
\text { zone crystals abundant. }\end{array}$ \\
\hline$"$ & (b) & Abundant osazone. & Abundant osazone. & $\begin{array}{l}\text { Liquid turbid at top only. } \\
\text { Osazone crystals abundant. }\end{array}$ \\
\hline Control. & (a) & No change. & $\begin{array}{l}\text { Brown film at top. } \\
\text { Liquid cloudy. }\end{array}$ & $\begin{array}{l}\text { Film and general turbidity } \\
\text { more marked. Yellow- } \\
\text { brown deposition on sides } \\
\text { of tube. }\end{array}$ \\
\hline$"$ & (b) & Quite clear. & Quite clear. & $\begin{array}{l}\text { Quite clear, except for top } \\
\text { layer (I-2 mm.), which } \\
\text { appeared turbid. }\end{array}$ \\
\hline
\end{tabular}

\begin{tabular}{|c|c|c|c|c|}
\hline \multicolumn{2}{|c|}{ Heated 60 mins. } & \multirow{2}{*}{$\begin{array}{l}\text { On cooling. } \\
\text { Little change. }\end{array}$} & \multirow{2}{*}{$\begin{array}{l}\text { After } 4 \text { days. } \\
\text { Little change. }\end{array}$} & \multirow{2}{*}{$\begin{array}{l}\text { After } 5 \text { weeks. } \\
\text { Film at top; yellow-brown } \\
\text { deposition on sides of tube; } \\
\text { liquid turbid. }\end{array}$} \\
\hline Cane sugar. & (a) & & & \\
\hline$" \quad$, & (b) & Quite clear. & Quite clear. & $\begin{array}{l}\text { Quite clear, except top layer } \\
\text { (3 mm.), which appeared } \\
\text { turbid. }\end{array}$ \\
\hline $\begin{array}{c}\text { Maltose. } \\
\text { " }\end{array}$ & $\begin{array}{l}(a) \\
(b)\end{array}$ & $\begin{array}{l}\text { Little change. } \\
\text { Quite clear. }\end{array}$ & $\begin{array}{l}\text { Little change. } \\
\text { Quite clear. }\end{array}$ & $\begin{array}{l}\text { Much the same as with } \\
\text { cane sugar. }\end{array}$ \\
\hline $\begin{array}{c}\text { Dextrose. } \\
\quad,\end{array}$ & $\begin{array}{l}(a) \\
(b)\end{array}$ & $\begin{array}{l}\text { Abundant osazone. } \\
\text { Quite clear. }\end{array}$ & $\begin{array}{l}\text { Abundant osazone. } \\
\text { Quite clear. }\end{array}$ & $\begin{array}{l}\text { Abundant osazone. } \\
\text { Quite clear, except at top. }\end{array}$ \\
\hline Levulose. & (a) & Abundant osazone. & Abundant osazone. & \\
\hline$"$ & (b) & $\begin{array}{l}\text { Osazone began to form } \\
\text { after a time. }\end{array}$ & $\begin{array}{l}\text { Abundant osazone. } \\
\text { Crystals smaller than } \\
\text { in }(a) \text {. }\end{array}$ & Abundant osazone. \\
\hline Control. & (a) & Liquid somewhat cloudy. & $\begin{array}{l}\text { Liquid cloudy, with } \\
\text { film at top. }\end{array}$ & $\begin{array}{l}\text { Brown film at top; deposition } \\
\text { on sides of tube. }\end{array}$ \\
\hline$"$ & (b) & Quite clear. & Quite clear. & $\begin{array}{l}\text { Quite clear, except top layer } \\
\text { (3 mm.), which appeared } \\
\text { brown and turbid. }\end{array}$ \\
\hline
\end{tabular}




\begin{tabular}{|c|c|c|c|}
\hline $\begin{array}{l}\text { Heated } 75 \text { mins. } \\
\text { (E'c.). }\end{array}$ & On cooling. & After 4 days. & After 5 weeks. \\
\hline $\begin{array}{cc}\text { Cane sugar. } & (a) \\
\Rightarrow \quad " \quad(b)\end{array}$ & $\begin{array}{l}\text { Very slight precipitate. } \\
\text { Quite clear. }\end{array}$ & $\begin{array}{l}\text { Very slight precipitate. } \\
\text { Quite clear. }\end{array}$ & $\begin{array}{l}\text { Very slight precipitate. } \\
\text { Quite clear, except top layer. }\end{array}$ \\
\hline Maltose. & Little change. & Little change. & $\begin{array}{l}\text { Film at top; liquid rather } \\
\text { turbid. No osazone crystals. }\end{array}$ \\
\hline (b) & Quite clear. & Quite clear. & Quite clear, except top layer. \\
\hline Control. & Little change. & Little change. & $\begin{array}{l}\text { Film at top ; liquid turbid ; } \\
\text { yellow-brown deposition on } \\
\text { sides of tube. }\end{array}$ \\
\hline (b) & Quite clear. & Quite clear. & Quite clear, except top layer. \\
\hline
\end{tabular}

Several conclusions may be drawn from the above results, though the experiment was merely a preliminary one and by no means strictly quantitative :

I. In the presence of excess of pure glycerine the formation of crystalline osazones may be hindered or entirely prevented.

2. This effect appears to be more pronounced with maltose and dextrose than with levulose.

3. In the presence of water (in excess) chemical changes occur leading to the formation of brown substances, but glycerine (in excess) tends to prevent or retard these changes. Their first appearance at the surface exposed to air suggests that these changes are oxidation processes. They extend into the pure glycerine mixtures more slowly than into the aqueous ones.

4. The reagent itself in the presence of excess of pure glycerine undergoes no appreciable change even after being heated at about $100^{\circ} \mathrm{C}$. for more than an hour; the addition of water, however, brings about the changes referred to in 3 .

5. Cane sugar may yield a small quantity of osazone crystals if heated for more than an hour, ${ }^{1}$ though excess of glycerine was found to prevent the reaction in this particular instance.

Some quantitative experiments were then made in the following manner :

Experiment II. Weighed amounts of the dry, powdered sugars were introduced into glass tubes and just dissolved in a drop or two of water. Carefully mixed reagent was then added in known weight.

The respective tubes contained cane sugar, (I) I per cent. (i. e. 0.02 gr. sugar and $2.0 \mathrm{gr}$. reagent), (2) 10 per cent. (i. e. $0.20 \mathrm{gr}$. sugar and $2.0 \mathrm{gr}$. reagent) ; dextrose, I per cent.; levulose, I per cent. ; and maltose, (I) I per cent., (2) Io per cent. 
When prepared the tubes were corked, heated for one hour at $98^{\circ} \mathrm{C}$, and examined on cooling and subsequently from time to time.

The results given are shown below:

\begin{tabular}{|c|c|c|c|c|}
\hline , & On removal. & After I day. & After 3 days. & After 4 days. \\
\hline Cane sugar, I \% & Clear yellow. & Slightly turbid. & $\begin{array}{l}\text { Little change. Thin } \\
\text { film at top. }\end{array}$ & Much the same. \\
\hline$" \quad$ " $10 \%$ & Clear yellow. & Slightly turbid. & More turbid. & $\begin{array}{l}\text { Slight deposi- } \\
\text { tion of osazone } \\
\text { crystals. }\end{array}$ \\
\hline Dextrose, I \% & $\begin{array}{l}\text { Clear yellow. Crys- } \\
\text { tals had formed } \\
\text { half an hour later. }\end{array}$ & Plenty of crystals. & $\begin{array}{l}\text { Abundance of small } \\
\text { osazone crystals } \\
\text { forming a precipi- } \\
\text { tate at bottom of } \\
\text { tube. }\end{array}$ & Much the same. \\
\hline Levulose, I \% & $\begin{array}{l}\text { Practically a solid } \\
\text { mass of osazone } \\
\text { and glycerine. Tube } \\
\text { invertible within } \\
5 \text { minutes. }\end{array}$ & Much the same. & $\begin{array}{l}\text { Much the same. Crys- } \\
\text { tals, being larger } \\
\text { than those given by } \\
\text { dextrose, were more } \\
\text { uniformly distri- } \\
\text { buted. }\end{array}$ & Much the same. \\
\hline Maltose, I \% & $\begin{array}{l}\text { Clear yellow (as I \% } \\
\text { cane sugar). }\end{array}$ & Slightly turbid. & Much the same. & Much the same. \\
\hline 10 $\%$ & $\begin{array}{l}\text { Darker yellow, but } \\
\text { quite clear. }\end{array}$ & Slightly turbid. & Much the same. & Much the same. \\
\hline
\end{tabular}

In order to follow the changes microscopically drops of the mixtures were also mounted on slides having depressions ground in one surface, and the cover-slips were attached with wax mixture. ${ }^{1}$

\begin{tabular}{|c|c|c|c|c|c|}
\hline & After $\frac{1}{2}$ hour. & After I day. & After 3 days. & After 4 days. & After 45 days. \\
\hline Cane sugar, I \% & $\begin{array}{l}\text { Minute yellow- } \\
\text { brown globules. }\end{array}$ & Little change. & Little change. & Little change. & $\begin{array}{l}\text { No osazone crys- } \\
\text { tals. }\end{array}$ \\
\hline$, \quad, \quad 10 \%$ & $\begin{array}{l}\text { More numerous } \\
\text { globules than } \\
\text { in I \%. }\end{array}$ & $\begin{array}{l}\text { Moderate number } \\
\text { of crystals. }\end{array}$ & $\begin{array}{l}\text { Increase in number } \\
\text { of crystals. }\end{array}$ & $\begin{array}{l}\text { Abundance of } \\
\text { crystals though } \\
\text { much less than } \\
\text { in I \% dextrose. }\end{array}$ & $\begin{array}{l}\text { Abundantspheri- } \\
\text { cal clusters of } \\
\text { crystals, dense, } \\
\text { almost woolly, } \\
\text { outline not } \\
\text { sharp. } \\
\left(=\text { 'd.l.' type.) }{ }^{3}\right.\end{array}$ \\
\hline Dextrose, I \% & $\begin{array}{l}\text { Crystallization set } \\
\text { in almost at } \\
\text { once. Spherical, } \\
\text { rather feathery } \\
\text { aggregates of } \\
\text { fine, acicular, } \\
\text { short crystals. } \\
(=' d \text { ' type. })^{2}\end{array}$ & Little change. & $\begin{array}{l}\text { Plenty of mode- } \\
\text { ratelylarge crystal } \\
\text { clusters with great } \\
\text { numbers of very } \\
\text { much smaller, less } \\
\text { dense ones present } \\
\text { between them. }\end{array}$ & Much the same. & Much the same. \\
\hline
\end{tabular}

1 Minute crystals may be present in the glycerine, and although these may not be visible to the naked eye, they become obvious under the microscope.

2 Cf. Pl. XVII, Fig. 2.

${ }^{3}$ Cf. Pl. XVII, Fig. 3. 


\begin{tabular}{|c|c|c|c|c|c|}
\hline & After $\frac{1}{2}$ hour. & After I day. & After 3 days. & After 4 days. & After 45 days. \\
\hline Levulose, I \% & $\begin{array}{l}\text { Sheaves of long, } \\
\text { fine, acicular } \\
\text { crystals formed } \\
\text { before mount- } \\
\text { ing. } \\
\left(=' l^{\prime} \text { 'type. }\right)^{1}\end{array}$ & Little change. & $\begin{array}{l}\text { Crystal aggregates } \\
\text { very distinct from } \\
\text { those of dextrose. }\end{array}$ & Much the same. & Much the same. \\
\hline Maltose, I \% & $\begin{array}{l}\text { Minute globules } \\
\text { of golden syrup. } \\
\text { Liquid as a } \\
\text { whole a deeper } \\
\text { yellow than in } \\
\text { cane sugar or } \\
\text { blank tests (i.e. } \\
\text { the reagent } \\
\text { alone). }\end{array}$ & No crystals. & $\begin{array}{l}\text { Many drops but } \\
\text { no crystals. }\end{array}$ & Much the same. & Much the same. \\
\hline$" 10 \%$ & $\begin{array}{l}\text { More numerous } \\
\text { and larger glo- } \\
\text { bules of syrup, } \\
\text { and deeper } \\
\text { colour as a } \\
\text { whole than in } \\
\text { I \%. }\end{array}$ & No crystals. & $\begin{array}{l}\text { A number of crys- } \\
\text { tal aggregates- } \\
\text { coarse sheaves, } \\
\text { spheres, and ir- } \\
\text { regular clusters } \\
\text { of rather blunt- } \\
\text { ended crystals, } \\
\text { broader than } \\
\text { those of ' } d \text { ' or } \\
\text { ' } l \text { ' apparently } \\
\text { forming from } \\
\text { drops of syrup } \\
\text { in some cases. } \\
\text { Some finer crystals } \\
\text { also present. }\end{array}$ & $\begin{array}{l}\text { More numerous } \\
\text { crystals. Quite } \\
\text { distinct from } \\
\text { the ' } d \text { ' and ' } l \text { ' } \\
\text { types. } \\
\text { The finer crys- } \\
\text { tals, however, } \\
\text { resemble indi- } \\
\text { viduals of the } \\
\text { ' } d \text { ' clusters. }\end{array}$ & $\begin{array}{l}\text { Still larger num- } \\
\text { ber of clusters, } \\
\text { some united in } \\
\text { chains. Very } \\
\text { characteristic. } \\
\text { Many of the } \\
\text { masses quite } \\
\text { opaque. } \\
(=m \text { 'type. })^{2}\end{array}$ \\
\hline
\end{tabular}

Although they do not form a complete series, these experiments bring out several interesting points.

In the case of I per cent. mixtures which had been heated for an hour it is seen that levulose and dextrose yielded copious crystalline precipitates. The osazone came down more rapidly with levulose than with dextrose, ${ }^{3}$. and in the former connsisted of sheaves of long, fine, acicular crystals which contrasted strongly with the more spherical and somewhat feathery clusters of smaller, though acicular crystals given by dextrose. ${ }^{4}$

The cane-sugar mixture underwent little change, though some yellow drops of syrup appeared to have formed.

The maltose mixture turned much yellower, and showed minute droplets of syrupy liquid more conspicuously than did the cane-sugar mixture.

1 Cf. Pl. XVII, Fig. I.

${ }^{2}$ Cf. P1. XVII, Fig. 4.

3 This difference was observed by Senft. See also below.

4 It may be remarked that these two types of crystal clusters can hardly be regarded as altogether distinctive characters for dextrose and levulose. In low concentrations the difference is less pronounced and may quite disappear. The two forms are referred to as ' $d$ ' (dextrose) and ' $l$ ' (levulose) types in the results to be described in a later paper, while ' $d . l$.' indicates such denser, woolly, spherical clusters as are yielded by cane sugar, and ' $m$ ' denotes the maltose type. 


\section{of locating Sugars in Plant Tissues.}

The Io per cent. mixture of cane sugar yielded rather dense, lumpy clusters of crystals. The amount increased for a time, but the final yield was much smaller than that given by either of the I per cent. mixtures of the constituent hexoses.

The Io per cent. mixture of maltose yielded crystals after standing for two or three days. The amount increased for some days, and the crystals, which were quite distinct in form, appeared to arise from the drops of syrupy liquid mentioned above. The presence of finer crystals in smaller quantity rather suggests that a certain amount of the maltose had undergone hydrolysis with the production of dextrose. Glycerine has, indeed, been shown to have a hydrolytic action upon cane sugar and upon maltose. ${ }^{1}$

It is, however, apparent that in the case of the I per cent. mixture of cane sugar hydrolysis had not proceeded sufficiently to cause a precipitation of osazones from the resulting invert sugar.

On the other hand, after the Io per cent. mixture had been heated for an hour, enough of the cane sugar had become hydrolysed to produce a good crop of crystals.

It is clear, then, that attempts to distinguish cane sugar qualitatively in presence of its constituent hexoses by comparing the yields of osazones obtained in duplicate preparations, only one of which has been heated, ${ }^{2}$ cannot give trustworthy results, since the formation of a precipitate with cane sugar demands its presence in a relatively high minimum concentration if the duration of heating is not to be prolonged unduly.

Still less reliability attaches to the method as a quantitative one, for from the above examples it is evident that after heating for one hour similar osazone yields would result if each of the pair of preparations contained both dextrose and cane sugar in I per cent. strength. Indeed the presence of cane sugar, in addition to the hexose, would not be detected by eye any too readily unless present in several times the above amount.

That Senft was led to attach too much importance to this method of attempting to distinguish cane sugar doubtless arose from using 50 per cent. sugar solutions, ${ }^{3}$ and apparently neglecting to check the results so obtained by comparison with those given by weaker solutions more comparable in concentration with the contents of plant cells.

To a certain extent the work of Strakosch, ${ }^{4}$ who employed the method in an investigation on the sugars of the beet, is open to criticism on the grounds of unreliable technique, and only those of his conclusions with

1 Donath ('94). Grafe records ('05, p. 2I) that maltose undergoes some hydrolysis after I $-\mathrm{I} \frac{\mathbf{1}}{\mathbf{2}}$ hours heating with Senft's reagent.

2 Hexoses alone slowly yield osazones in the cold.

3 Senft, 1. c., p. Io.

4 Strakosch ('07), p. 862. Cf. also Ruhland ('12), pp. 219-22, for criticisms. 
regard to cane sugar which were founded on evidence other than that derived in the above manner can be regarded as at all trustworthy. ${ }^{1}$

The identification of maltose by the formation of osazones does not appear to have been investigated by Senft. ${ }^{2}$

Grafe $^{3}$ noted and figured the characteristic flat, broad needles of maltose phenylosazone as yielded by Senft's reagent, and such crystals have also been figured by the present writer in an earlier paper. ${ }^{4}$

In the experiments just described, and in others of a similar character, the process of formation of the crystals of maltose phenylosazone was followed under the microscope.

It is slow and changes may take place over many days, though with the stronger solutions, or with more prolonged heating, the time is shortened.

The liquid first changes to a deeper yellow, and small drops looking much like 'golden syrup' appear, the amount of this syrup being roughly proportional to the concentration of maltose present. These drops gradually become confluent to form larger drops, or by partial union they may form irregular chains of globules, or again they may yield masses whose contours show obvious signs of their formation by the coalescence of smaller globules. These larger drops of yellowish-brown to very pale yellow syrup may undergo no further change, or if the concentration is sufficiently high they may begin to show signs of the formation of radially arranged, needleshaped crystals. Ultimately the larger drops give rise to fairly regular, spherical clusters of rather broad, straight, light yellow. needles whose points are usually more or less obtuse. Besides these regular, spherical clusters of radiating crystals other more irregular arrangements are to be found as well as single needles. Frequently a number of crystal clusters form in contact, and become arranged in straight or irregularly curved rows with slight constrictions indicating the component clusters. Often the osazone appears as an almost opaque mass, the crystalline nature of which cannot be made out, or is perhaps only recognizable at portions of the external surface.

Examples of these forms are shown in Pl. XVII, Figs. 4-7.

The formation of crystals of maltose phenylosazone after heating for one hour depends then in part upon the original concentration of the sugar in the glycerine, and it seems to be hindered by the great viscosity of this liquid. In low concentrations the syrup stage of the osazone may not be

1 Cf. also below, p. 379 .

2 Senft records (1. c., p. 25) that in a few instances, after the preparations had stood for some fourteen days, rosettes and sheaves of yellow crystals formed. He considered that these were probably osazones. Cf. Pl. II, Figs. 8-I I, where characteristic crystals of maltose phenylosazone are shown in Ginkgo, Daucus, and Elodea.

${ }^{3}$ Grafe, 1. c., Pl. I, Figs. 4 and 5. In the latter crystals are apparently forming from yellow liquid.

4 Mangham ('11), p. I64, Figs. 3 and 4. See also Plimmer ('10), p. 7I, Fig. I4. 
passed even after six months, while in higher concentrations crystals may appear in a day or two, or even within a few hours if the heating is more prolonged.

Considerable caution must therefore be exercised in attempting to locate maltose in starch-forming plants by means of Senft's reagent. The formation of drops of syrupy liquid within cells, especially if in any quantity, and if in tissues examined after starch dissolution is known to have occurred, in all probability denotes the presence of maltose, though other possibilities are not altogether excluded. ${ }^{1}$

If actual crystals are formed the osazone can be identified with less uncertainty, though here again it is necessary to bear in mind alternative interpretations. $^{2}$

Here it may be remarked that the failure of Strakosch to detect maltose regularly in the leaves of the beet, and his finding of only small quantities in the petiole, ${ }^{3}$ may perhaps have been caused partly by the failure of the osazone to crystallize in glycerine.

The effect of glycerine upon the crystallization of the osazones was further investigated by mixing the latter with glycerine in various proportions, heating the mixtures, and allowing them to cool prior to examining them microscopically.

Experiment III. Levulose and dextrose phenylosazones were added to pure glycerine so as to give $0 \cdot I$ per cent., $\mathrm{I} \cdot 0$ per cent., and 5 per cent. mixtures. The tubes containing these were then heated and shaken until the contents appeared homogeneous. The colour of the resulting liquid varied from straw to dark brown according to the concentration of the osazone.

Drops were mounted immediately after heating and mixing, and were examined microscopically at once.

The results obtained are shown in the table below.

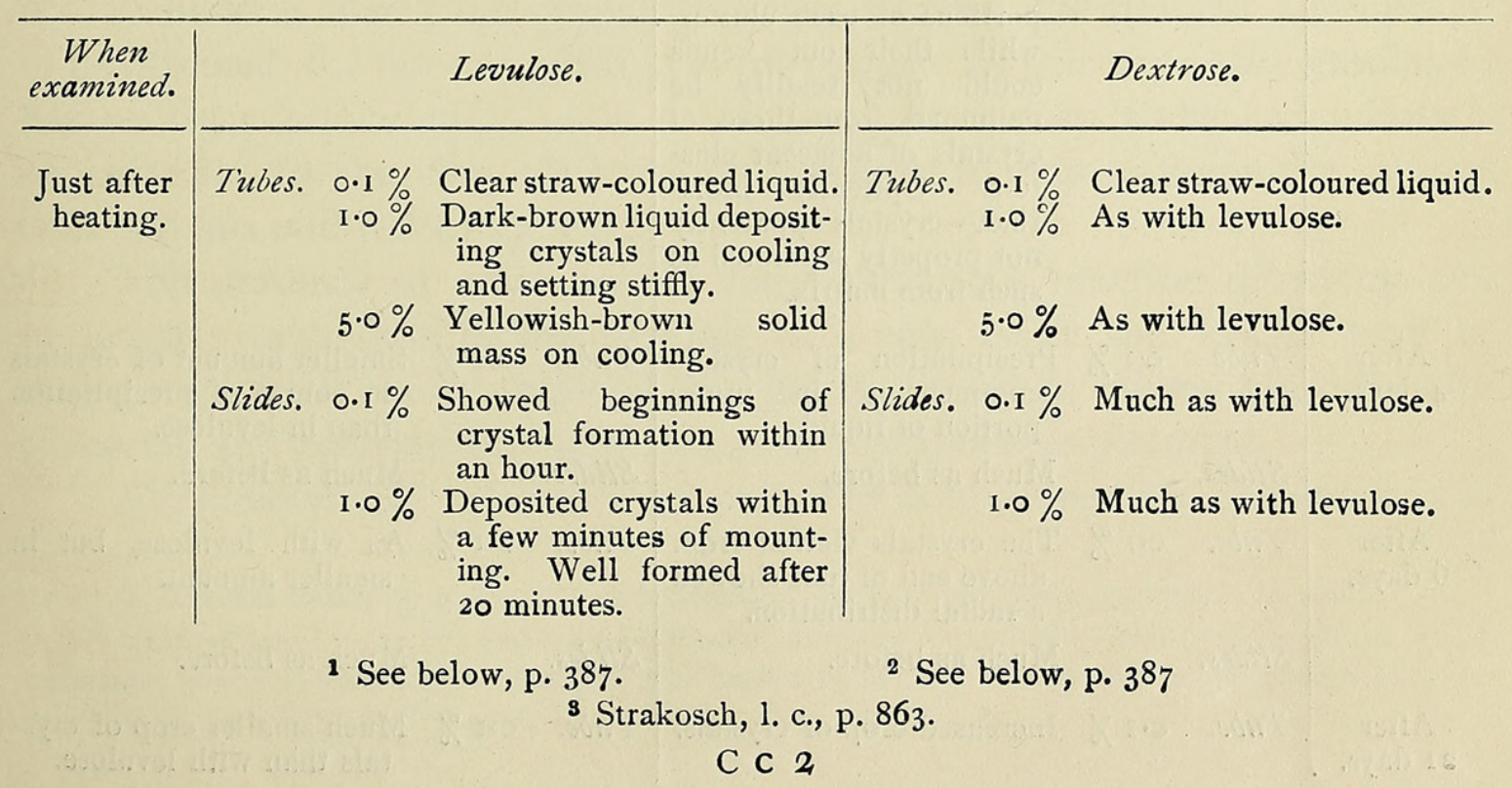




\begin{tabular}{|c|c|c|c|c|c|}
\hline $\begin{array}{l}\text { When } \\
\text { examined. }\end{array}$ & \multicolumn{2}{|r|}{ Levulose. } & \multicolumn{3}{|r|}{ Dextrose. } \\
\hline \multirow[t]{2}{*}{$\begin{array}{l}\text { After } \\
\text { I } 8 \text { hours. }\end{array}$} & $\begin{aligned} & \text { Tubes. } 0.1 \% \\
& \mathrm{I} \cdot 0 \%\end{aligned}$ & $\begin{array}{l}\text { Quite clear. Straw-coloured. } \\
\text { No further change. }\end{array}$ & Tubes. & $\begin{array}{l}0.1 \% \\
1.0 \%\end{array}$ & $\begin{array}{l}\text { Quite clear. Straw-coloured. } \\
\text { No further change. }\end{array}$ \\
\hline & Slides. O.I \% & $\begin{array}{l}\text { Good crop of short, small, } \\
\text { acicular crystals, mostly } \\
\text { separate, but some in } \\
\text { sheaves or groups. }\end{array}$ & Siides. & I.0\% & $\begin{array}{l}\text { A distinctly smaller crop of } \\
\text { crystals than with O.I \% } \\
\text { levulose. Crystals con- } \\
\text { fined to edges of depression } \\
\text {-not in latter itself, as } \\
\text { with levulose. Individual } \\
\text { crystals indistinguishable } \\
\text { from those of levulose. } \\
\text { Much as with levulose. }\end{array}$ \\
\hline
\end{tabular}

After 42 hours.

Tube. $0.1 \%$ Still quite clear to naked eye. A drop removed and examined microscopically, however, showed a few small crystal clusters and one or two larger ones. Some almost transparent, flocculent masses or films of irregular outline also microscopically visible.

Slides. 0.1 \% Very good crop of crystals, separate or in sheaves, throughout the liquid.

I.0 \% Dense mass of spherical crystal clusters. The radiating crystals most clearly defined in central portions of each cluster, while their outer ends could not readily be delimited from those of crystals of adjacent clusters. Optically indistinct-crystals apparently not properly separated as such from matrix.

After 4 days.

After

6 days.

After

$2 I$ days.
Tube. O.I \% Precipitation of crystals commencing in upper portion of liquid.

Slides. $\quad$ Much as before.

Tube. $0.1 \%$ The crystals viewed from above end of tube showed a radial distribution.

Slides. $\quad$ Much as before.

Tube. $\quad$ 0.I \% Increased crop of crystals.
Tube. O.I \% Still quite clear to the eye. A drop examined microscopically showed distinctly fewer crystals than with $0.1 \%$ levulose. Flocculent masses as with levulose - possibly osazone about to crystallize.

Slides. 0.I \% An increased number of crystals present practically all round edge of depression, but not yet in latter. Similar in appearance to levulose, but much less in quantity.

I.0 \% Much as with levulose.

Tube. 0.I \% Smaller amount of crystals in course of precipitation than in levulose.

Slides. Much as before.

Tube. 0.I \% As with levulose, but in smaller amount.

Slides. Much as before.

Tube. 0.I \% Much smaller crop of crystals than with levulose. 


\begin{tabular}{|c|c|c|c|c|c|}
\hline $\begin{array}{l}\text { When } \\
\text { examined. }\end{array}$ & & Levulose. & & & Dextrose. \\
\hline $\begin{array}{l}\text { After } \\
47 \text { days. }\end{array}$ & Slides. & Much the same. & Slide. & $1.0 \%$ & $\begin{array}{l}\text { Crystals more clearly de- } \\
\text { fined. }\end{array}$ \\
\hline $\begin{array}{l}\text { After } \\
57 \text { days. }\end{array}$ & Slides. & $\begin{array}{l}\text { Little further change. } \\
\text { Crystal formation did } \\
\text { not appear to have pro- } \\
\text { gressed as with dextrose. } \\
\text { Very hazy and turbid or } \\
\text { granular, except at centres } \\
\text { of clusters. }\end{array}$ & Slides. & $\begin{array}{l}0.1 \% \\
1.0 \%\end{array}$ & $\begin{array}{l}\text { Little change. } \\
\text { Crystal formation appa- } \\
\text { rently complete. Innu- } \\
\text { merable very minute } \\
\text { crystals everywhere, be- } \\
\text { sides larger clusters. }\end{array}$ \\
\hline
\end{tabular}

From these results it would appear that the osazones are fairly soluble in hot glycerine, but that on cooling they come down as crystals readily in mixtures of I per cent. concentration and above, but less readily in O.I per cent. mixtures.

In the I per cent. mixtures the actual crystal clusters of levulose were ultimately less sharply defined than those of dextrose in this particular instance.

It is also seen that a O.I per cent. mixture of levulose phenylosazone deposits crystals more rapidly and copiously than a corresponding mixture of the osazone yielded by dextrose.

The two osazones are almost insoluble in glycerine, ${ }^{1}$ but in weak concentrations crystallization seems to be retarded by the viscosity of the glycerine. Naturally in a viscous medium the rate of diffusion of particles to form crystals is slower than in a medium such as water. Clearly, too, the process of crystallization will be slower when the particles are highly dispersed throughout the medium than when they are present in greater concentration.

On the whole, then, although there may be some irregularity at times, it may be held that if the preparations are allowed due time for equilibrium to be attained, the use of glycerine in the reagent as it is ordinarily employed has no very serious effect upon the delicacy of the test as far as levulose is concerned. In the case of dextrose, however, it may occasionally happen that crystals will fail to appear. ${ }^{2}$

The presence of other sugars may affect the reaction given by any particular sugar, but before dealing with this point the results may be described which were obtained by mixing maltose phenylosazone with glycerine and treating the mixtures as in the above experiment.

Experiment $I V$. Tubes were prepared containing the osazone mixed

1 The actual solubility has not been determined, but it is obviously less than I in I,000.

${ }^{2}$ Grafe states (1. c., p. I 7 ) that a 0.015 per cent. solution of dextrose yields positive results. It is not clear, however, whether this concentration means I $_{5}$ parts in 100,000 of the reagent or of water previous to the addition of reagent. 
with pure glycerine in ten different proportions, viz. I per cent., 2 per cent., 3 per cent., 4 per cent., 5 per cent., 6 per cent., 8 per cent., Io per cent., I 5 per cent., and 20 per cent.

As in previous experiments drops of the mixtures were mounted on slides, sealed and examined microscopically at intervals over a long period.

The behaviour of maltose phenylosazone under these conditions differed markedly from that of the osazones of dextrose and levulose.

No rapid re-crystallization occurred, but the preparations showed a series of changes which took place with extreme slowness.

After the tubes had cooled, their contents ranged in colour from pale straw to very deep brown. ${ }^{1}$ With the rise in concentration of the osazone the viscosity of the mixture increased, the 20 per cent. mixture being almost invertible. ${ }^{2}$ Owing to the opacity of the higher mixtures satisfactory observations could not be made on them in the tubes.

In all the less opaque tubes a slight increase in turbidity was noticed for a few days from the commencement of the experiment.

After four days the tubes up to 6 per cent. showed a somewhat less opaque top layer.

Observations made upon the prepared slides showed that suspended in the fluid medium were numerous very minute globules of yellowish-brown syrup. In any one slide these globules varied in size over a not very wide range. Their number increased more or less in proportion to the concentration of the osazone.

On examining the preparations by dark-ground illumination and with a Zeiss $\mathrm{I} 6 \mathrm{~mm}$. objective and $\times$ I 8 compensating ocular the presence of an immense number of minute particles could be detected. These were best seen in the weaker mixtures, and according to their size they scattered rays of different wave length, and so appeared as bright red, orange, green, \&c., points of light.

The number of points of light which could be detected by dark-ground illumination was much greater than that of the globules visible by weak transmitted light.

It was possible to observe an extremely slow motion of the points of light in the glycerine, i.e. slow, compared with the motion of colloidal particles in a metallic hydrosol.

The minute yellowish-brown globules showed a fortuitous arrangement at first, but gradually, and more obviously in the higher concentrations, they became grouped to form irregular clusters leaving spaces more or less free. Many of the globules cohered, and some by coalescence gave rise to larger ones. By the fourth day this grouping of globules into chains, \&c.,

1 Probably due to small amounts of aniline or decomposition products present as impurities.

${ }^{2}$ Cf. the hexoses, pp. 379-8o. It is possible to prepare emulsions of oil and soap having a consistency allowing of cubes being cut out of them. Hatschek ('13), p. 22. 
had become quite evident and numbers of large globules were to be seen surrounded by smaller ones just in contact with them.

Besides this gradual grouping and coalescence of yellowish-brown globules another change soon became evident. When weak light was used a pale yellow substance in the form of more or less regular spheres, often with somewhat darker centres, appeared on the lower surfaces of the cover-slips.

This change was first noticed in the stronger mixtures, but later on it appeared in the weaker ones also. It was observed on about the third day in the 8 per cent. mixture and in those of higher concentration, on the sixth day in the 6 per cent. mixture, the twelfth day in the 5 per cent. mixture, and some days later in the 4 per cent. mixture. Below this strength the pale yellow substance had not appeared after nine weeks from the beginning of the observations, although it was then very noticeable in all concentrations above 3 per cent. At the end of this period the first three slides showed only globules of brownish syrup of various sizes irregularly grouped as described above. (Cf. Pl. XVII, Fig. 8.)

The actual nature of these globules has not been determined, but it is considered probable that they were due partly to impurities, either introduced with the osazone or resulting from decomposition produced by local overheating, and partly to osazone which had been melted, ${ }^{1}$ but had not been brought by the heating into a state of fine division, and so had yielded visible droplets of syrup.

At the same time in the 4 per cent. mixture the pale yellow substance took the form of numerous approximately regular spheres having a diameter of the order of ten times that of the average globule of brownish syrup, of which numbers were also present.

Most of these spheres were single, but in some cases two or more appeared fused and occasionally rows of them were formed.

About five weeks later the 3 per cent. mixture showed a small number of these pale yellow spheres. (Cf. P1. XVII, Fig. 9.) After four months from the commencement of the observations the number of spheres had increased, but none were visible in the 2 per cent. mixture. (Cf. Pl. XVII, Fig. 8.)

In the higher concentrations the amount of the light yellow substance was proportionately greater. While in the 8 per cent. mixture the spheres were for the most part just in contact with one another, above this strength their closeness and fusion caused the preparations to appear opaque and coarsely granular.

It has not been possible to make out the exact structure of these spheres. In many cases they resembled drops of pale yellow liquid, while in a few instances the slightly roughened outline and somewhat granular

${ }^{1}$ Melting-point of maltose phenylosazone, $206^{\circ} \mathrm{C}$. Boiling-point of glycerine, $290^{\circ} \mathrm{C}$. The osazone is liable to decompose in air at melting-point; cf. Armstrong ('12), p. 60. 
appearance recalled some stages observed in the formation of osazone crystals in preparations in which maltose had been heated with the reagent.

On the whole it seemed fair to conclude that the osazone, which as the result of being heated had melted and had then been dispersed throughout the glycerine as an emulsion and partly as a solution, on cooling had gradually become aggregated into microscopically visible droplets which were in some cases very slowly undergoing re-crystallization from the syrupy condition.

Although after six months from the time of mounting some of these spheres appeared distinctly more crystalline, the majority were still almost transparent and structureless.

In addition to these observations, others were made on preparations which contained drops of the I per cent. and 5 per cent. mixtures described above, and which had been heated at $98^{\circ} \mathrm{C}$. or so for $\frac{1}{2}$ hour, I hour, $\mathrm{I} \frac{1}{2}$ hours, and 2 hours respectively after having been set up.

The early stages of the processes just dealt with were somewhat accelerated by the heating. About four months later it was found that, while the I per cent. mixtures which had been heated for I hour and $I \frac{1}{2}$ hours respectively showed only drops of yellowish-brown syrup, there also appeared in the other two I per cent. preparations a great number of much larger, pale yellow, spherical, semi-crystalline or granular masses. (Cf. Pl. XVII, Fig. Io.)

These evidently consisted of osazone partially re-crystallized, and so afforded an example of a later stage in the process than could be seen in any of the unheated slides. After six months from the beginning of the experiment the osazone in all of these slides was found to have partially re-crystallized.

It is clear, therefore, that even in I per cent. concentration the viscous syrup may under suitable conditions slowly crystallize.

Crystallization is, however, uncertain and the osazone may remain either in solution or as a fine emulsion, or it may separate out as microscopically visible drops of syrup which apparently do not crystallize.

Doubtless in this case, as with other organic compounds, the presence of impurities hinders crystallization of the syrup. It is known that in aqueous solutions the form of the crystals of maltose phenylosazone is greatly affected by small traces of impurities. ${ }^{1}$ In the plant cell many substances are present and must constitute impurities; among these are colloids, the influence of which on crystallization may be very marked.

Accordingly some lack of uniformity of the osazone of maltose is to be expected when it is formed inside vegetable cells, and especially inside sieve-tubes where proteins may abound.

It cannot, of course be taken for granted that results yielded by extra-

$$
1 \text { Armstrong, 1. c., p. } 60 .
$$


cellular experiments will hold good for reactions carried out inside plant cells, for it is impossible to realize the precise conditions obtaining in the latter. Still it may be urged that the above results and considerations afford some justification for regarding as maltose phenylosazone the yellow syrup so often observed inside cells (especially the sieve-tubes of fine veins in leaves) after treating with Senft's reagent sections of veins, petioles, \&c., taken from starch-forming leaves which had previously been placed under conditions ensuring hydrolysis of starch and translocation of sugar.

Furthermore, it may be suggested that the production of an apparently homogeneous syrup in these cells probably indicates the presence of maltose alone, ${ }^{1}$ while the appearance which has been recorded in notes of experiments as 'semi-crystalline', 'amorphous', or 'granular', and which has been found on the whole less commonly in the sieve-tubes of the finer veins of leaves than in those of the stronger ones, would then denote either maltose ${ }^{2}$ from which osazone crystals had formed (or were forming) and were mingled with some uncrystallized syrup, or a mixture of maltose with other sugars.

For example, such an appearance might well be produced if maltose, in the course of translocation, gradually became hydrolysed under the action of maltase produced by the sieve-tubes themselves or by the companioncells, ${ }^{3}$ or if hydrolysis occurred during the heating of the preparations. ${ }^{4}$ The resulting dextrose would yield osazone crystals, but there would probably be some syrup as well if any maltose remained, and in the confined space of the sieve-tubes the two would be obliged to mix to a certain extent.

Again, if in addition to maltose cane sugar had entered the sieve-tubes, and sufficient of it had become hydrolysed either during the heating or previously while undergoing translocation, a deposit of crystalline osazone might be formed and so produce the appearance referred to.

Finally, there might also be present with the maltose before treatment with the reagent hexoses which had not arisen from the hydrolysis of bioses. ${ }^{5}$

\section{Reaction with Mixtures of Sugars.}

It was remarked above that the presence of other sugars may influence the osazone reaction given by any particular sugar.

In this connexion considerable interest attaches to the work of Scherman and Williams, ${ }^{6}$ who studied the rate of precipitation of osazones from aqueous solutions of one or more sugars. Other conditions being unchanged, they found that the rate of precipitation with dextrose varied with

1 Probably in low concentration.

3 Cf. Scott ('89), p. I 56.

2 Probably in higher concentration.

4 Cf. above, p. 377.

5 In this connexion cf. Brown and Morris ('93), Strakosch, 1. c., Parkin ('11), Ruhland, 1. c., Campbell ('12), and Armstrong, 1. c.

${ }^{6}$ Scherman and Williams ('06): 
the concentration of the solution and was approximately constant for any given dilution.

Similar results were obtained with levulose, which, however, always gave a precipitate in about one-third of the time required by the same amount of dextrose.

Invert sugar yielded the osazone almost as rapidly as levulose of the same concentration.

The rate of precipitation was accelerated by the addition of certain other sugars. For example, the time required for precipitating the osazone from a solution containing 0.1 per cent. of dextrose was shortened considerably in the presence of 5 per cent. raffinose, a sugar giving no direct reaction itself.

Cane sugar was found to produce a similar acceleration with levulose solutions.

On the other hand, maltose, and to a greater extent lactose, retarded the precipitation and interfered much more seriously in the case of dextrose than in the case of levulose.

These results obtained in aqueous solutions have not been compared fully with those given in glycerine solutions. But some of the earlier experiments carried out by the author before becoming acquainted with the above work showed that mixtures of dextrose and maltose gave the reaction less readily than mixtures of levulose and maltose, and that in a mixture of dextrose and levulose the reaction did not appear to be at all hindered. ${ }^{1}$ Moreover, in the case of the levulose and maltose mixture typical levulose osazone crystals were found on examining immediately after the heating, whereas no crystals could be seen in the dextrose and maltose mixture until about two hours later, and then small ones slowly formed. A similar dextrose solution alone gave large crystals immediately on cooling. In these experiments the preparations were heated for half an hour.

As the behaviour of dextrose and levulose in glycerine is on the whole much the same as in water, there is little reason for doubting that the results obtained in aqueous solutions would apply also when the reaction is carried out with Senft's reagent, although the effect would be intensified owing to the viscosity of the glycerine.

Here then is another reason for allowing due time to elapse before drawing conclusions from the application of the reagent to plant tissues known to form starch and thus likely to contain maltose and dextrose.

Various points in connexion with the use of Senft's reagent in botanical work have now been dealt with, but one or two more call for remarks.

Oxidation. The formation of brown substances in presence of air, and more rapidly when water is present too, has been referred to above. This

1 These experiments were only roughly quantitative, as drops of 5 per cent. aqueous solutions were added to Senft's reagent in approximately equal amounts in the various cases. 
is probably due to the oxidation of the reagent, for phenylhydrazine has not good keeping properties when freely exposed to the air. Pure glycerine acts as a preservative, presumably because it prevents ready access of air. The products formed give in glycerine brown drops of syrup (cf. foot-note below).

The glycerine itself might conceivably undergo oxidation ${ }^{1}$ by the action of substances present locally in the plant, in which case small quantities of such compounds as glyceric aldehyde or dihydroxyacetone might be formed, and these substances yield osazones. To examine this point some glycerine was oxidized with aqueous ferrous sulphate and hydrogen peroxide, ${ }^{2}$ and the brown substance (osazone) resulting from the subsequent addition of Senft's reagent was examined microscopically. The (dilute) glycerine mixture yielded drops of brown syrupy liquid, some opaque brown spherical masses, and some crystal clusters, the individual crystals of which had the form of lamellae almost as broad as long and with obtuse ends. To some extent such crystals resemble those yielded by maltose phenylosazone, and might possibly be mistaken for them if not closely examined. The syrup is practically indistinguishable from that of the maltose osazone, although rather darker in colour.

It should be noted that the reagent itself, when tested in blank experiments used as controls to those in which sugar had been added, did not give crystals ; if properly filtered in preparation very little syrup is formed either. ${ }^{3}$

On the whole the danger of mistaking for crystals of maltose phenylosazone those of the osazone of an oxidation product of glycerine is small under the conditions in which the test is ordinarily applied.

Salts of Phenylhydrazine. Phenylhydrazine readily forms salts with acids, and some of these are insoluble in glycerine and water. The hydrochloride is fairly soluble in glycerine, the acetate also, but the oxalate is less soluble. The crystals, however, are in each case quite distinct in form from those of maltose phenylosazone. Moreover they are typically colourless, but might easily appear yellowish in the proximity of yellow osazones. While in general these crystals are distinguishable still in some arrangements, especially when viewed edgewise, and when at all inclined to appear yellow, careful examination may be necessary to determine their real identity.

1 In contact with platinum black glycerine in presence of air and water produces glyceric aldehyde, $\mathrm{CO}_{2}$ and water. Watts, ii, p. 616. In contact with iron oxidizing in moist air, a substance like glucose is formed. Ibid., p. 617 .

2 Fenton ('06), p. IOI.

8 Cf. p. 370, foot-note I. If, however, the reagent is old when applied, or is heated for a long time in presence of air, yellowish-brown liquid and crystalline or opaque masses may be formed after standing for some months. It is advisable to renew the phenylhydrazine hydrochloride solution at least once every six months, though Senft states (1. c., p. 7 ) that the reagent may be used satisfactorily even if three years old. 


\section{SUMMARY.}

The results of this investigation may now be brought together.

To carry out the test sections of plant tissues are laid in a mixture of glycerine solutions of phenylhydrazine hydrochloride and of sodium acetate, and then are heated at $98^{\circ}-100^{\circ} \mathrm{C}$., usually for an hour.

During the heating to which the tissues are subjected some diffusion of cell contents may occur, but this is certainly less than that resulting from the use of aqueous reagents such as Fehling's solution. On the whole positive results (osazone formation) may be held to indicate with a fair degree of accuracy the distribution of the reacting sugars before treatment with the reagent.

The reaction is affected by the glycerine employed; the glycerine acts mainly by reason of its viscosity and causes a retardation of processes depending upon diffusion.

The amount of this retardation varies with different sugars, and apparently is not altogether constant for the same sugar.

Levulose yields an osazone very readily, and in preparations heated for half an hour the crystals are often formed before cooling. Frequently the crystals are long and fine, and are arranged in sheaves.

Dextrose precipitates its osazone less readily than levulose, and with very small concentrations of dextrose a positive result may occasionally not be given. As a rule the crystals are shorter, and are formed in spherical clusters having a feathery outline. With I per cent. of the sugars present the crystal clusters contrast strongly in the two hexoses, but in low concentrations this difference disappears. With 0.1 per cent. of the osazones present the crystals are small and indistinguishable, and are deposited after a few hours, but more readily and copiously in the case of levulose.

Too much reliance should not be placed on the crystal cluster form as a feature distinguishing dextrose from levulose.

Glycerine is known to have a hydrolytic effect on cane sugar and maltose.

Cane sugar, if present in sufficient concentration, may become partly hydrolysed after being heated at $98^{\circ}-100^{\circ} \mathrm{C}$. for an hour. In an experiment with I per cent. of the sugar present no osazone crystals were formed. With Io per cent. a good crop of dense, lumpy crystal clusters was obtained, but the yield was much less than that given by a $\mathrm{I}$ per cent. dextrose mixture.

It follows that attempts to detect cane sugar in presence of its constituent hexoses by comparing the osazone yield in duplicate preparations, one of which only has been heated (hexoses alone react slowly in the cold), cannot give very reliable results and may be quite misleading.

The presence of water appears to accelerate the hydrolysis of cane 
sugar, so that as a little water is present in tissues at the commencement of heating, it is quite possible that the reagent is more sensitive to cane sugar in actual practice than the above experiments would suggest. Moreover, an acid cell-sap, \&c., would assist in the hydrolysis of the cane sugar.

Maltose, after being heated for an hour, forms a golden yellow syrup from which crystals may slowly form. In a mixture containing I per cent. of sugar only the syrup was produced, and this appeared in the form of a coarse emulsion; but with a Io per cent. mixture, after a day or two, there resulted a small crop of fairly large, straight, linear-lanceolate, obtuseended crystals arranged either radially in spherical clusters or in various irregular groupings. The yield increased slowly over a number of days. Many of the clusters were almost opaque, and their crystalline nature could only with difficulty be made out.

The presence of impurities in the form of various cell contents, particularly colloidal substances, probably influences the crystallization of the syrupy osazone, and may account for some irregularity in its behaviour in plant tissues.

From observations on the process of crystallization of maltose phenylosazone in glycerine, it is concluded that the production of a golden yellow syrup inside starch-forming cells, or conducting cells of starch-forming organs, which have previously been treated with Senft's reagent, very probably indicates the presence of maltose.

It is suggested that a commonly observed granular appearance of this liquid may be due to one or more of the following causes:

(a) Crystallization of syrupy maltose phenylosazone ;

(b) Partial hydrolysis of maltose originally present with production of dextrose and its osazone; this may occur during the heating in Senft's reagent, or the maltose may have been undergoing enzyme hydrolysis at the time of applying the reagent;

(c) Similar hydrolysis of cane sugar present with maltose, and consequent production of invert sugar yielding osazones;

(d) Presence of maltose, together with hexoses not produced by hydrolysis of disaccharides, i. e. 'up-grade' hexoses.

Maltose appears to retard precipitation of osazone crystals of the hexoses ; this effect is more marked with dextrose than with levulose.

The reagent itself gives no crystals after two or three hours' heating, and if properly filtered in preparation only small traces of syrup are formed. If old, however, or much exposed to air, the reagent alone after heating for an hour or so may yield crystalline compounds and syrup after some months standing. This does not occur in properly closed preparations in which moderately fresh reagent has been used. The presence of water assists in the formation of these products. It is as well to renew the phenylhydrazine hydrochloride solution at least once every six months. 
There is a slight possibility of mistaking for the osazone of maltose other crystals such as those of salts of phenylhydrazine, or of the oxidation products of glycerine should these be formed.

In conclusion, it may be said that when using Senft's reagent it is advisable to re-examine the preparations from time to time over a period of at least four months before attempting to draw conclusions from them.

\section{LITERATURE CITED.}

Armstrong, E. F. ('12): The simple Carbohydrates and the Glucosides.

Brown, H. T., and Morris, G. H. ('93): A Contribution to the Chemistry and Physiology of Foliage-leaves. J. Chem. Soc., vol. lxiii, pp. 604-77; abstract in Ann. of Bot., vol. vii, pp. $27 \mathrm{I}-89$.

Campbell, A. V. ('12): The Carbohydrates of the Mangold Leaf. J. Agric. Sci., vol. iv, pp. $248-59$.

Donath, E. ('94) : J. f. prakt. Chem., vol. xlix, pp. $546,55^{6}$.

Fenton, H. J. H. ('06): Notes on Qualitative Analysis.

GRAFE, V. ('05) : Studien über den mikrochemischen Nachweis verschiedener Zuckerarten in den Pflanzengeweben mittels der Phenylhydrazinmethode. Sitzber. Akad. Wien, mathem.naturw. Kl., Bd. cxiv, Abth. I, pp. I $5^{-28}$.

Hatschek, E. ('13): Introduction to the Chemistry and Physics of Colloids.

Mangham, S. ('10): The Paths of Translocation of Sugars from Green Leaves. Rep. Brit. Ass., Sheffield.

('10-'11): The Translocation of Carbohydrates in Plants. Science Progress, vol. v, pp. $25^{6}-85,457-79$.

('11): On the Detection of Maltose in the Tissues of certain Angiosperms. New Phytologist, vol. x, pp. I60-6.

PARkin, J. ('11): Carbohydrates of the Snowdrop Leaf and their Bearing on the First Sugar of Photosynthesis. Biochem. Journ., vol. vi, pp. I-47 ; abstr. in Nature, I9I 2, pp. 395-6.

Plimmer, R. A. ('10): Practical Physiological Chemistry.

Ruhland, W. ('12): Untersuchungen über den Kohlenhydratstoffwechsel von Beta vulgaris. Pringsh. Jahrb. f. wiss. Bot., vol. 1, pp. 200-57.

Scherman, H. C., and Williams, R. H. ('06) : Journ. Amer. Chem. Soc., vol. xxviii, p. 629.

Scott, D. H. ('89): On some recent Progress in our Knowledge of the Anatomy of Plants. Ann. of Bot., vol. iii, p. ${ }^{\mathrm{I}} 56$.

SENFT, E. ('04): Über den mikrochemischen Zuckernachweis durch essigsaures Phenylhydrazin. Sitzber. Akad. Wien, mathem.-naturw. Kl., Bd. cxiii, Abth. I, pp. 3-28; abstr. in Bot. Centralbl., pp. 28-9.

Strakosch, S. ('07): Ein Beitrag zur Kenntnis des Kohlenhydratstoffwechsels von Beta vulgaris. Sitzber. Akad. Wien, mathem.-naturw. Kl., Bd. cxvi, Abth. I, pp. 855-69.

Thomas, H. Hamshaw ('11): New Phytologist, I05-6.

WATTS: Dictionary of Chemistry (MORLEy and MuIR).

\section{DESCRIPTION OF PHOTOMICROGRAPHS IN PLATE XVII.}

\section{Illustrating Mr. Mangham's paper on the Osazone Method of locating Sugars in Plant Tissues.}

Fig. I. Osazone crystals yielded by I per cent. of levulose in Senft's reagent after heating for one hour. Photographed four months after heating. $\times$ I I 4 .

Fig. 2. Osazone crystals yielded by I per cent. of dextrose in Senft's reagent after heating for one hour. Photographed four months after heating. Note feathery edges of crystal clusters. $\times$ I I4. 
Fig. 3. Osazone crystals yielded by to per cent. of cane sugar in Senft's reagent after heating for one hour. Photographed four months after heating. $\times$ II 4 .

Fig. 4. Osazone yielded by Io per cent. of maltose in Senft's reagent after heating for one hour. Photographel four months after heating. Many of the masses were almost opaque. $\times$ II 4 .

Note.-Figs. I-4 are not intended to indicate the relative amounts of osazone produced, but to illustrate the types of crystal aggregates formed.

Fig. 5. Drops of syrup formed after maltose had been heated with Senft's reagent. Photographed one month after heating. $\times$ circa $\mathrm{I} 2 \mathrm{O}$.

Fig. 6. Stages in the formation of crystals of maltose phenylosazone from yellow syrup. Photographed one month after heating. $\times$ circa $\mathbf{I} 20$.

Fig. 7. An individual crystal cluster of maltose phenylosazone, showing blunt-ended crystals. $\times$ circa $\mathrm{I} 80$.

Fig. 8. Drops of syrup yielded by 2 per cent. of maltose phenylosazone, after being heated in glycerine and allowed to cool. Photographed four months after heating. $\times 500$.

Fig. 9. From a 3 per cent. mixture of maltose phenylosazone in glycerine, heated and allowed to cool, showing drops of syrup and larger pale yellow spheres. Photographed four months after heating. $\times 500$.

Fig. 10. From a I per cent. mixture of maltose phenylosazone in glycerine after a second heating. Note the more crystalline appearance of the osazone. Photographed four months after heating. $\times \mathrm{II}_{4}$. 


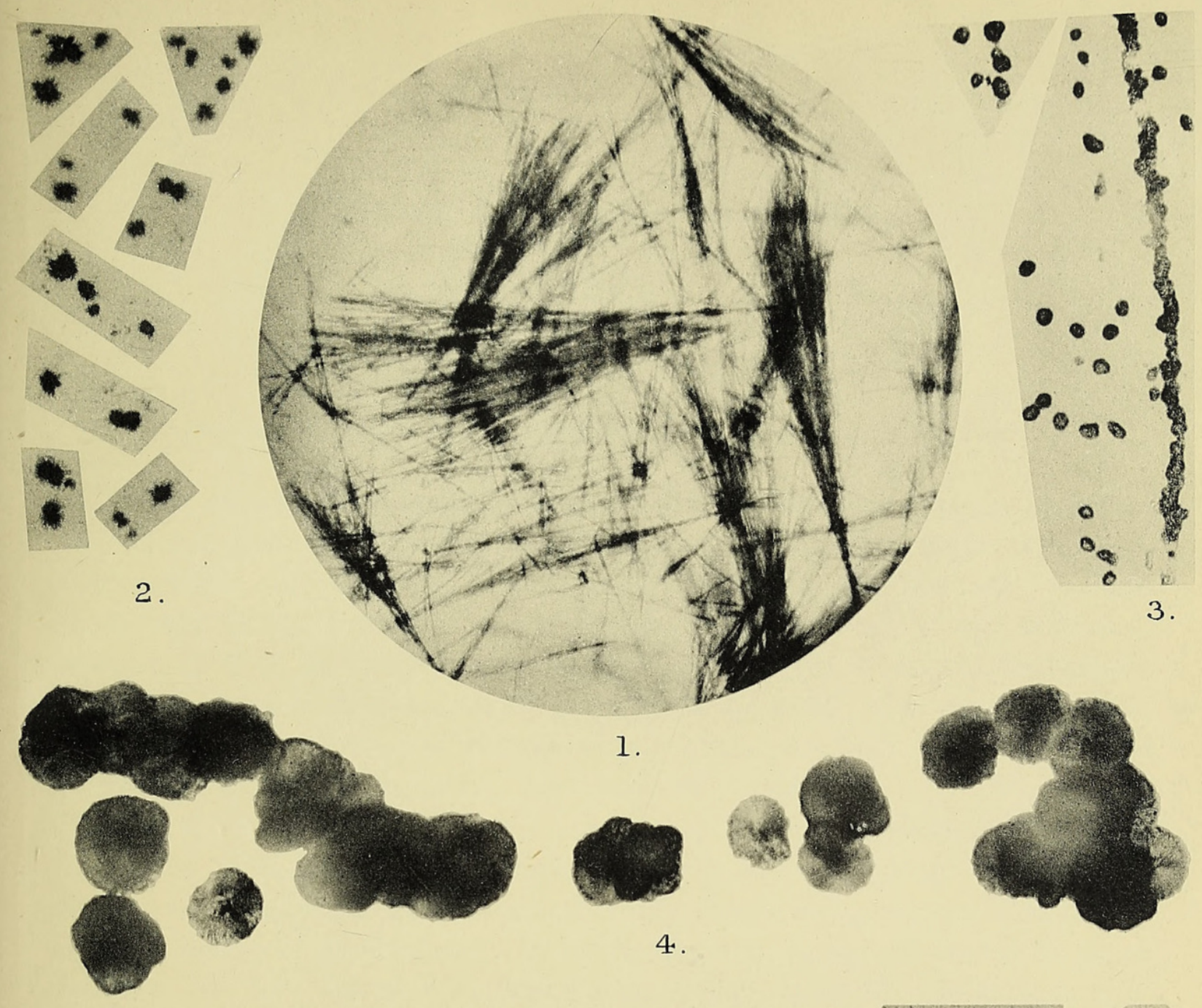

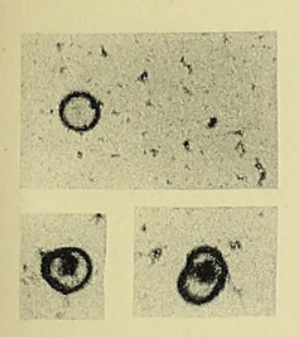

5.

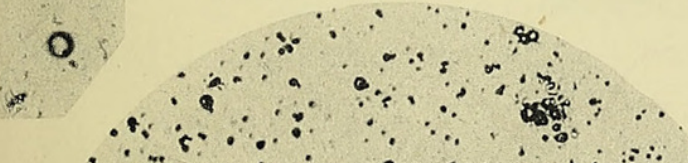

$\therefore \quad \therefore \quad \therefore \quad \therefore \quad \therefore \quad \therefore \quad \therefore \quad \therefore \quad \therefore \quad \therefore \quad \therefore$

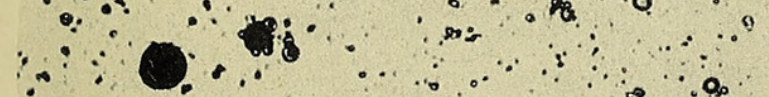

$\because \because \therefore \therefore \quad \because \quad \because \cdots$

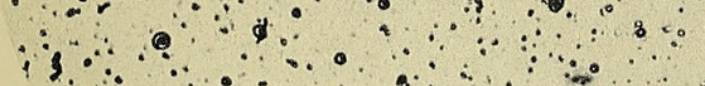

$\because \therefore \because \because \quad \because \quad \because \quad \because$

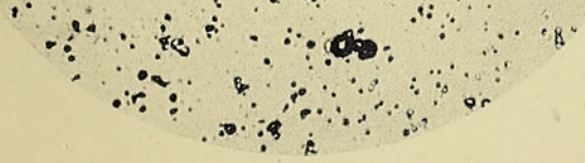

8.
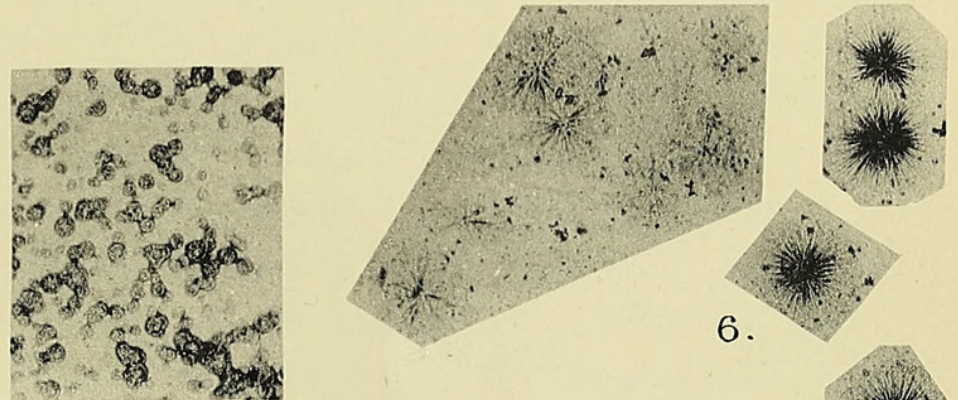

6.

10.

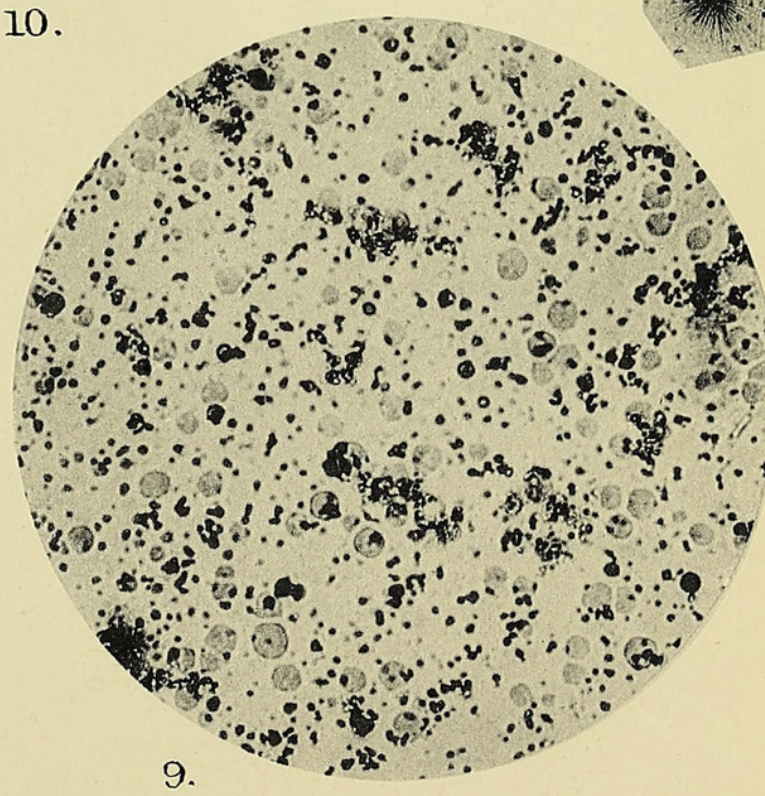

Huth, coll 


\section{$2 \mathrm{BHL}$ Biodiversity Heritage Library}

Mangham, Sydney. 1915. "Observations on the osazone method of locating sugars in plant tissues." Annals of botany 29, 369-391. https://doi.org/10.1093/oxfordjournals.aob.a089553.

View This Item Online: https://www.biodiversitylibrary.org/item/243629

DOI: https://doi.org/10.1093/oxfordjournals.aob.a089553

Permalink: https://www.biodiversitylibrary.org/partpdf/320070

\section{Holding Institution}

Smithsonian Libraries

\section{Sponsored by}

Biodiversity Heritage Library

\section{Copyright \& Reuse}

Copyright Status: Not in copyright. The BHL knows of no copyright restrictions on this item.

This document was created from content at the Biodiversity Heritage Library, the world's largest open access digital library for biodiversity literature and archives. Visit BHL at https://www.biodiversitylibrary.org. 